\title{
Alternatives for spring forage emptiness in Pampa, Brazil
}

\section{Edgard Gonçalves Malaguez ${ }^{1}$, Gabriella Valduga Dinarte ${ }^{1}$, Leonardo Ereno Tadielo ${ }^{1}$, Nathaly Lopes Toledo dos Santos ${ }^{1}$, Deise Dalazen Castagnara ${ }^{1}$}

\footnotetext{
${ }^{1}$ Universidade Federal do Pampa - UNIPAMPA, Campus Uruguaiana, Uruguaiana, Rio Grande do Sul, Brasil. E-mail: edgardgmalaguez@gmail.com, gabiduga@hotmail.com, leonardotadielo@hotmail.com, nathaly.lts@gmail.com, deisecastagnara@yahoo.com.br
}

Recebido: 03/04/2017; Aceito: 08/11/2017.

\begin{abstract}
The spring forage emptiness is an obstacle to the development of Brazilian livestock, including in the Bioma Pampa region. Feed strategies for this period contributed to the development of livestock and to the conservation of the biome. The objective of this work was to know the nutritional potential of forages during spring forage for use as strategies in the forage planning. The experiment had a completely randomized design, with ten forages and four replicates. The chemical composition, in vitro dry matter digestibility (IVDMD) and the total digestible nutrient content (NTD) of elephant grass, brachiaria cultivars Convert and Marandu, Tifton 68; diploid and tetraploid ryegrass; red, white and arrowleaf clover; and bird's-foot trefoil. The grasses had a higher proportion of fibrous constituents, and lower levels of NDT and DMD, thus, lower nutritional value. Negative correlation between mineral matter and fibrous constituents with CP, TDN and IVDMD, was observed. Forages studied can be used as pasture alternatives for ruminants in the spring forage emptiness of the Pampa, Brazil, however, the strategy of using them should be a pasture planning.
\end{abstract}

Palavras-chave: dry matter digestibility, total digestible nutrients, crude protein.

\section{Alternativas para o vazio forrageiro primaveril no Pampa, Brasil}

\section{RESUMO}

O vazio forrageiro primaveril é um entrave ao desenvolvimento da pecuária brasileira, inclusive na região do Bioma Pampa. Estratégias alimentares para este período contribuem para o desenvolvimento da pecuária e para a conservação do bioma. Objetivou-se com este trabalho conhecer o potencial nutricional de forrageiras durante o vazio forrageiro primaveril para utilização como estratégias no planejamento forrageiro. Adotou-se o delineamento inteiramente casualizado, com dez forrageiras e quatro repetições. Foram estudadas a composição bromatológica, digestibilidade in vitro da matéria seca (DIVMS) e os teores de nutrientes digestíveis totais (NDT) do capim elefante, braquiárias Convert e Marandu, Tifton 68; azevéns diplóide e tetraplóide; trevos vermelho, branco e vesiculoso; e cornichão. As gramíneas apresentaram maior proporção de constituintes fibrosos, e menores teores de NDT e DIGMS, portanto menor valor nutricional. Constatou-se correlação negativa entre a matéria mineral e constituintes fibrosos com a PB, NDT e DIVMS. As forrageiras estudadas podem ser usadas como alternativas de pastagens no vazio forrageiro primaveril do Pampa, Brasil, porém, a estratégia de utilização das mesmas deve perfazer um planejamento forrageiro.

Key words: digestibilidade na matéria seca, nutrientes digestíveis totais, proteína bruta. 


\section{Introduction}

The production of ruminants in Brazil is based on natural or cultivated pastures, and is commonly characterized by extractivism (BARCELLOS et al., 2008), especially when carried out in natural fields such as the Pampa region of Brazil. Agricultural practices based on extractivism cause environmental liabilities and limit the profitability of activities and the productive capacity of natural resources over time.

In the region of Pampa, Brazil, ruminant livestock has a social and economic role in the region's development, influencing its economy and culture (Boldrini, 2009). However, it is still developed under erroneous practices especially in pasture management, for example overgrazing (NABINGER et al., 2009) and inefficiency or lack of forage planning, whose consequences are low productivity and compensation. In this context, to be replaced by other crops or activities, it requires the adoption of technologies to improve indexes and higher productive efficiency (BARCELLOS et al., 2011) with consequent improvements in economic results (DILL et al., 2015).

Among these technologies, the use of new forage alternatives to supplement animal feeding during periods critical to the development of pastures that make up the Pampa fields is particularly noteworthy. The use of winter grasses and legumes is adopted by the production systems and softens the existing fodder void during the winter period. Among them, oats and ryegrass are found in isolated or consorted crops (GUZATTI et al., 2015), as well as clover and elephant grass (ZIECH et al., 2016) and Tifton 68 (PARIS et al., 2016).

However, in other periods such as spring and autumn losses still occur due to low supply and low nutritional value of the feed available to the animals. In the void spring forage, the winter forages are declining in production and quality and the summer species are not in their best productive phase. In view of this, it is necessary to know the species that best play their nutritional role nowadays.

The objective of this work was to evaluate the nutritional characteristics of winter and summer forages that can be cultivated in the Pampa region, Brazil during the spring forage emptiness.

\section{Material and Methods}

The study was conducted as a completely randomized design with ten forages and four replications in the Pampa region, Brazil (latitude $29^{\circ} 49^{\prime} 60^{\prime \prime} \mathrm{S}$ and longitude $57^{\circ} 05^{\prime} 58^{\prime \prime} \mathrm{W}$, with an altitude of $79 \mathrm{~m}$ ), between the period of autumn-winter of 2014 season. The analyzes were conducted in the Laboratory of Animal Nutrition and Forage of the Federal University of Pampa.

Four tropical grasses were evaluated: elephant grass (Penisetum purpureum), bracharia brizantha cultivars Convert and Marandu, Tifton 68 (Cynodon dactylon); two winter grasses: ryegrass (Lolium multiflorum) diploid and tetraploid; and four winter legumes: red clover (Trifolium pratense), white clover (Trifolium repens), arrowleaf clover (Trifolium vesiculosum), bird's-foot trefoil (Lotus corniculatus).

The soil of the area is classified as Plintossolo haplico (Embrapa, 2006) and presented the following chemical characteristics: $\mathrm{pH}$ in water - 6,21; $\mathrm{P}$ (Mehlich-1) - 9,35 $\mathrm{mg} \mathrm{dm}^{-3}$; K (Mehlich) - 0,24 $\mathrm{cmol}_{\mathrm{c}}$ $\mathrm{dm}^{-3} ; \mathrm{Ca}^{2+}\left(\mathrm{KCl} 1 \mathrm{~mol} \mathrm{~L}^{-1}\right)-7,96 \mathrm{cmol}_{\mathrm{c}} \mathrm{dm}^{-3} ; \mathrm{Mg}^{2+}$ $\left(\mathrm{KCl} 1 \mathrm{~mol} \mathrm{~L}^{-1}\right)-4,90 \mathrm{cmol}_{\mathrm{c}} \mathrm{dm}^{-3} ; \mathrm{Al}^{3+}\left(\mathrm{KCl} 1 \mathrm{~mol} \mathrm{~L}^{-}\right.$ $\left.{ }^{1}\right)-2,32 \mathrm{cmol}_{\mathrm{c}} \mathrm{dm}^{-3} ; \mathrm{SB}-13,10 \mathrm{cmol}_{\mathrm{c}} \mathrm{dm}^{-3} ; \mathrm{CTC}-$ $15,42 \mathrm{cmol}_{\mathrm{c}} \mathrm{dm}^{-3} \mathrm{~V}-85 \%$, organic matter (Boyocus Method) - 23,24 $\mathrm{g} \mathrm{dm}^{-3}$; sand $-437 \mathrm{~g} \mathrm{~kg}^{-1}$; silt $-342 \mathrm{~g}$ $\mathrm{kg}^{-1}$ and clay $-221 \mathrm{~g} \mathrm{~kg}^{-1}$.

The experimental plots had dimensions of $12 \mathrm{~m}^{2}$ totaling an area of $480 \mathrm{~m}^{2}$. In the implementation of the test, elephant grass and Tifton 68 were implanted by piles and stolons, respectively, in December 2013, with spacing of $0.30 \mathrm{~m}$ between the lines and plants. After the forage establishment, the plots were harvested at intervals of 30 days in the summer period and 50 days in the winter period. The other forages were planted in July 2014, using seeds with seeding densities of $7 \mathrm{~kg}$ $\mathrm{ha}^{-1}$ for brachiaria brizantha, $35 \mathrm{~kg} \mathrm{ha}^{-1}$ for ryegrass, 5 $\mathrm{kg} \mathrm{ha}{ }^{-1}$ for Clovers and $8 \mathrm{~kg} \mathrm{ha}^{-1}$ to the Bird's-foot trefoil. During the experimental period the accumulated rainfall was $273 \mathrm{~mm}$ and the average air temperature was $17^{\circ} \mathrm{C}$ (INMET, 2017).

Samplings for the verification of nutritional value were carried out in September 2014. At the time, all forages were in the vegetative stage. Brachiaria and Elephant grass were aged at 55 days, while those implanted by seeds with 73 days of development. The forage samples were collected by means of the simulated grazing technique, at alternate points in the plots, discarding a $1.0 \mathrm{~m}$ border area and each side of the plot. At each sampling, approximately $300 \mathrm{~g}$ of forage were collected, which immediately after collection were submitted to drying in an oven with forced air ventilation for 72 hours at $55{ }^{\circ} \mathrm{C}$. After drying, the material was crushed and Willey mill, with knives and stainless-steel chamber and $1 \mathrm{~mm}$ sieve. All the samples obtained were submitted to laboratory procedures and the contents of mineral matter (MM), neutral detergent fiber (NDF), acid detergent fiber (ADF), lignin, crude protein (PB), as described by Silva and Queiroz (2009).

The digestibility parameters for DM and total digestible nutrients (TDN) were determined from the 
following equations: $\mathrm{DMD}=88.9-(0.7779 \mathrm{X} \% \mathrm{ADF})$ and $\mathrm{TDN}=87.84-(0.7 \mathrm{X} \% \mathrm{ADF})$, respectively, described in Teixeira e Teixeira (1998).

The analysis of variance and the comparison of averages by Tukey $(5 \%)$ were used in the statistical analysis. Initially all forages were compared to verify the ones with the highest nutritional potential. Afterwards, they were grouped in grasses and legumes and the statistical analysis was carried out again to identify the forage of greater nutritional potential within each group.

\section{Results and Discussion}

In all studied parameters, there was a significant difference between forages (Table 1). The mineral matter contents were lower in the legumes, which indicates that consequently these have higher levels of organic matter, and are potentially more nutritious because nutrients such as carbohydrates, lipids and proteins are included in the organic matter of food. Although the mineral matter acts as a nutritional source of minerals for the animals (SILVA; QUEIROZ, 2009), when it contains high proportions of silica can cause the reduction of fiber digestibility. This is due to the increase of silicon in the foliar tissues, also increases the cell wall deposition in the plants, making the tissues more rigid (RUPPENTAL et al., 2016) and less digestible. At the ruminal level, silicon is an important inhibitor of fiber digestion in bulks (PAIVA et al., 1995) because it interferes with the performance of ruminal microorganisms (BAE et al., 1997).

The NDF contents were higher in the grasses than in the legumes (Table 1), because the legumes belong to the group of plants with $\mathrm{C}_{3}$ cycle, presenting a slower growth rate, with lower structural carbohydrates deposition in their cell wall. The grasses, especially the tropical ones, because they are of the $\mathrm{C}_{4}$ cycle, present great productive capacity, but in dry matter accumulate, an expressive fraction is of structural carbohydrates (TAIZ; ZEIGER, 2009).

These structural carbohydrates are measured by the NDF content, which is a direct indication of the nutritional value of the forage, since it has a direct relation with the consumption, once NDF values higher than $550-600 \mathrm{~g} \mathrm{~kg}^{-1}$ cause in the reduction of the consumption caused by fill effect. (MERTENS et al., 2003). Therefore, the use of foods for the constitution of diets with high levels of neutral detergent fiber (NDF) may reduce feed costs, but may also promote restriction of food consumption due to the need for longer rumen food (BEZERRA et al., 2004). In the present study, it was possible to determine the viability of the microorganisms. The knowledge of the inhibitory potential and the present content of these constituents that affect the consumption of food have fundamental importance for the animal nutrition, therefore interfering in the consumption, also affect its performance, therefore, they must be considered in the formulation of the diets (ALSTRUP et al., 2016).

However, despite the high NDF content, this fraction is the main source of digestible energy for ruminants, especially those kept in regions with high forage production such as the tropics, and justifiable efforts are made to obtain NDF foods capable of interacting with microbial enzymatic systems responsible for their degradation and utilization (DETMANN et al., 2009). Likewise, mixed systems, with grasses and legumes can also provide the benefits described for lignin, the highest values were observed in tropical grasses, followed by legumes with more woody appearance (Table 1). However, due to the higher protein content observed in the leguminous plants, even with high lignin, the bird's-foot trefoil and the red clover showed higher DMD and TDN values than the grasses.

Table 1: Nutritional value of forages during the spring forage emptiness in the Pampa region, Brazil.

\begin{tabular}{lcclllllll}
\hline Forage plants & MM & NDF & ADF & HEM & CEL & LIG & CP & DMD & TDN \\
\hline Bird's-foot trefoil & $113,0 \mathrm{e}$ & $409,4 \mathrm{f}$ & $355,8 \mathrm{c}$ & $53,6 \mathrm{e}$ & $212,9 \mathrm{~b}$ & $134,6 \mathrm{a}$ & $270,5 \mathrm{a}$ & $611,8 \mathrm{c}$ & $629,3 \mathrm{c}$ \\
Arrowleaf Clover & $108,9 \mathrm{e}$ & $440,8 \mathrm{e}$ & $374,2 \mathrm{bc}$ & $66,5 \mathrm{ed}$ & $200,8 \mathrm{cb}$ & $96,5 \mathrm{c}$ & $200,3 \mathrm{~b}$ & $597,5 \mathrm{~cd}$ & $616,4 \mathrm{~cd}$ \\
White Clover & $116,8 \mathrm{e}$ & $358,3 \mathrm{~g}$ & $237,5 \mathrm{e}$ & $120,8 \mathrm{c}$ & $175,6 \mathrm{~b}$ & $72,3 \mathrm{~d}$ & $258,0 \mathrm{a}$ & $704,0 \mathrm{a}$ & $712,2 \mathrm{a}$ \\
Red Clover & $127,9 \mathrm{~d}$ & $413,0 \mathrm{f}$ & $312,2 \mathrm{~d}$ & $100,8 \mathrm{dc}$ & $196,2 \mathrm{cb}$ & $116,0 \mathrm{~b}$ & $267,2 \mathrm{a}$ & $645,8 \mathrm{~b}$ & $659,9 \mathrm{~b}$ \\
Diploid Ryegrass & $135,2 \mathrm{c}$ & $617,6 \mathrm{~b}$ & $398,3 \mathrm{ab}$ & $219,3 \mathrm{ba}$ & $189,9 \mathrm{cb}$ & $110,8 \mathrm{~b}$ & $109,0 \mathrm{~d}$ & $578,7 \mathrm{de}$ & $599,6 \mathrm{de}$ \\
Tetrapoid Ryegrass & $166,4 \mathrm{a}$ & $547,9 \mathrm{~d}$ & $357,0 \mathrm{c}$ & $190,9 \mathrm{~b}$ & $263,5 \mathrm{a}$ & $72,7 \mathrm{~d}$ & $157,6 \mathrm{c}$ & $610,9 \mathrm{c}$ & $628,5 \mathrm{c}$ \\
Tifton 68 & $161,9 \mathrm{a}$ & $660,2 \mathrm{a}$ & $430,8 \mathrm{a}$ & $229,4 \mathrm{ba}$ & $288,7 \mathrm{a}$ & $141,7 \mathrm{a}$ & $114,2 \mathrm{~d}$ & $553,4 \mathrm{e}$ & $576,9 \mathrm{e}$ \\
Elephant Grass & $169,7 \mathrm{a}$ & $571,4 \mathrm{c}$ & $374,6 \mathrm{bc}$ & $196,8 \mathrm{~b}$ & $290,3 \mathrm{a}$ & $85,3 \mathrm{~d}$ & $154,5 \mathrm{c}$ & $597,2 \mathrm{~cd}$ & $616,2 \mathrm{~cd}$ \\
Brachiaria Convert & $151,9 \mathrm{~b}$ & $621,4 \mathrm{~b}$ & $361,8 \mathrm{bc}$ & $259,6 \mathrm{a}$ & $260,6 \mathrm{a}$ & $108,2 \mathrm{~b}$ & $113,3 \mathrm{~d}$ & $607,1 \mathrm{~cd}$ & $625,1 \mathrm{~cd}$ \\
Brachiaria Marandu & $166,6 \mathrm{a}$ & $636,8 \mathrm{~b}$ & $396,9 \mathrm{ab}$ & $239,9 \mathrm{a}$ & $290,6 \mathrm{a}$ & $101,3 \mathrm{c}$ & $114,5 \mathrm{~d}$ & $579,8 \mathrm{de}$ & $600,6 \mathrm{de}$ \\
\hline Mean & 141,8 & 527,7 & 359,9 & 167,8 & 236,9 & 103,9 & 175,9 & 608,6 & 626,5 \\
\hline CV $(\%)$ & 3,3 & 2,4 & 4,2 & 10,6 & 6,5 & 11,1 & 3,6 & 2,0 & 1,7 \\
\hline$P$ value & $<0,000$ & $<0,000$ & $<0,000$ & $<0,000$ & $<0,000$ & $<0,000$ & $<0,000$ & $<0,000$ & $<0,000$ \\
\hline
\end{tabular}

* Averages followed by the same letter in the column do not differ by the Tukey test (5\%). P value: $\mathrm{p}$ value by Fischer's $\mathrm{F}$ test. MM: mineral matter; NDF: neutral detergent fiber; LIG: lignin; CB: crude protein; DMD: dry matter digestibility; TDN: total digestible nutrients. 
As lignin is quantified along with NDF, because although it is not a fibrous carbohydrate the lignin is adhered to the cell wall, and it is the main responsible for the reduction in the digestibility of the NDF, thus, foods with low lignin values reflect higher potential of digestibility of NDF. The reduction of the digestibility of NDF in foods with high lignin is due to the potential that it exerts on the ruminal microorganisms, both by the toxicity of the phenolic compounds and by the physical barrier formed to prevent the attack of the microorganisms (VAN SOEST, 1994).

The crude protein was higher in the legumes due to the constituents of its tissues, which accumulate more nitrogen and proteins (TAIZ; ZEIGER, 2009). However, even when dealing with the spring forage emptiness that is not the optimal growth season of any off the forages studied, all of them, including grasses, had $\mathrm{CP}$ levels higher than $70 \mathrm{~g} \mathrm{~kg}^{-1}$, minimum recommended for ruminal functioning (VAN SOEST, 1994). By associating the NDF and CP values, it is confirmed that all forages studied could be used as the only source of forage for ruminants in maintenance, as they did not present protein or fibrous restrictions for their use. However, when adopting diets for beef cattle that increase the minimum protein for ruminal functioning, there are many benefits to animal performance, especially because of the crucial role that nitrogen derived from protein compounds plays in ruminal microbial activity (DETMANNET et al., 2014).

Adequate nitrogen supply favors microbial multiplication and consequently increases the digestibility of the diet, even diets with forages with moderate to high contents of fibrous constituents. In these situations, these constituents act as energy source, contributing to energy balance: protein. This production condition could be obtained for example by using the legumes of this study in consortium with the grasses or as a protein bank for nitrogen supplementation to the animals.
The use of quality fresh forage as the main food source for ruminants is positive from the point of view of food safety, as it requires less quantities of food that can be used in human food for the supplementation of animals as well as from the health and welfare point of view. Being. Animal ingestion behavior is also affected by the type of food, chemical composition, particle size and by the feeding environment (NASCIMENTO et al., 2013; PERES NETTO et al., 2014). In order to determine the availability of feed, there is an optimization by the animals in the time available for the forage harvest (PERES NETTO et al., 2014), indicating their preference for this food source, due to the possibility of selection (MEZZALIRA et al., 2011) and increased ruminal health provided. In addition, a greater use of the diet, conditioned by the quality of the forage offered (VIBART et al., 2010) provides better conditions of animal welfare. These aspects have become more relevant in the scientific environment with discussions about animal welfare and the advancement of investigations that contemplate the processes involved between the animal, its environment and the process of obtaining its food (MEZZALIRA et al. 2011).

Correlation analysis showed a positive correlation between the fibrous constituents and the mineral and negative matter between them and CP, DMD and TDN (Table 2). These results confirm that the increase of the mineral matter is related to the increase of the fibrous constituents (RUPPENTAL et al., 2016) and negative with the nutritional value of the forage due to the negative effect of the silicon. Likewise, the increase in the fibrous constituents causes a decrease in $\mathrm{CP}$ and TDN contents and consequently in forages digestibility (MCDONALD et al., 2011). In addition, considering the studied species, to the positive aspects related to their nutritional value, other characteristics proven scientifically to be promising for use in ruminant feeding, especially during periods of forage emptiness.

Table 2. Pearson correlation between forage constituents during spring fodder vacuum in the Pampa region, Brazil.

\begin{tabular}{|c|c|c|c|c|c|c|c|c|}
\hline & NDF & $\mathrm{ADF}$ & HEM & CEL & LIG & $\mathrm{CP}$ & DMD & TDN \\
\hline MM & $0,787^{* *}$ & $0,478^{* *}$ & $0,801^{* * *}$ & $0,873^{* *}$ & $-0,091$ & $-0,715^{* *}$ & $-0,478^{* *}$ & $-0,478^{* *}$ \\
\hline NDF & & $0,780^{* *}$ & $0,895^{* *}$ & $0,719^{* *}$ & 0,194 & $-0,954^{* *}$ & $-0,780^{* *}$ & $-0,780^{* *}$ \\
\hline $\mathrm{ADF}$ & & & $0,419^{* *}$ & $0,576^{* *}$ & $0,464^{* *}$ & $-0,703^{* *}$ & $-0,999^{* *}$ & $-0,999^{* *}$ \\
\hline HEM & & & & $0,633^{* *}$ & $-0,049$ & $-0,883^{* *}$ & $-0,419^{* *}$ & $-0,419^{* *}$ \\
\hline CEL & & & & & 0,044 & $-0,632^{* *}$ & $-0,576^{* * *}$ & $-0,576^{* *}$ \\
\hline LIG & & & & & & $-0,022$ & $-0,464^{* *}$ & $-0,464^{* *}$ \\
\hline $\mathrm{CP}$ & & & & & & & $0,703^{* *}$ & $0,703^{* *}$ \\
\hline DMD & & & & & & & & $0,999^{* * *}$ \\
\hline
\end{tabular}

** Significant correlation at 1\% probability. MM: mineral matter; NDF: neutral detergent fiber; LIG: lignin; PB: crude protein; DIGMS: dry matter digestibility; NDT: total digestible nutrients. 
The Birdsfoot Trefoil has been shown to be a promising forage for the Pampa region, with a dry matter production ranging from 2000 to $4000 \mathrm{~kg} \mathrm{ha}^{-1}$ (STROSCHEIN et al., 2011), which, together with its nutritional value (Table 1), makes it a forage option for the region, especially in periods of forage emptiness as the spring. In addition, their high tannin content (STROSCHEIN et al., 2011) reduces the degradability of the protein at ruminal level and increases the nondegradable protein in the digestible dietary rumen (MEZZOMO et al., 2015). However, the use of the cornichon is positive in the region of the Pampa, Brazil, since it has been pointed out as one of the most promising forage for use in the improvement of native fields of the region (STROSCHEINET et al., 2011).

The composition observed for the white and red clovers were similar to those observed by Alstrup et al. (2016), who studied clover pastures in the four seasons of the year as alternatives for the production of silages for dairy cattle. These forages have great potential for use in ruminant feed, for example, replacing some of the protein sources such as soybean in diets for dairy cattle (KROLOW et al., 2012). They also have versatility of use, and can be used both in consortium systems with winter forages (OLIVO et al., 2010) and in summer (ZIECH et al., 2016).

Ryegrass is recommended as winter-spring grass (CARVALHO et al., 2010) due to its growth cycle, and as for all forage plants a reduction in their nutritional value is expected with the season's growth and plants' growth (VAN SOEST, 1994). However, even during the evaluation, spring and summer entry periods, pastures of the tetraploid ryegrass analyzed, presented NDF and $\mathrm{CP}$ levels close to 550 and $160 \mathrm{~g} \mathrm{~kg}^{-1}$, respectively. These results suggest the use of these pastures even for medium-production lactating cows (NRC, 2001). However, grasses of diploid ryegrass presented higher levels of NDF $\left(617 \mathrm{~g} \mathrm{~kg}^{-1}\right)$ and lower CP $\left(109 \mathrm{~g} \mathrm{~kg}^{-1}\right)$ than tetraploid ryegrass, suggesting a higher proportion of plant support structures in detriment of leaves (GUZATTI et al., 2015). However, even with inferior nutritional composition, diploid ryegrass becomes an alternative food for categories of medium nutritional requirement of cattle and cut (NRC, 2001) in situations of difficulty in obtaining seeds or implantation of tetraploid ryegrass.

Tifton 68 is recommended because it has the same advantages as other grasses of the Cynodon genus, such as perennial growth, rapid establishment of high forage yield (PARIS et al., 2016) and high animal load. Its nutritional characteristics described in the literature are similar to other grasses of the same genus (OLIVEIRA et al., 2016). However, in this study the values of digestibility (553 $\left.\mathrm{g} \mathrm{kg}^{-1}\right)$ and crude protein $\left(114 \mathrm{~g} \mathrm{~kg}^{-1}\right)$ were affected by the evaluation period, revealing a forage with medium nutritional value and requiring care for use during this period.

The elephant grass is a forage widely used for grazing or cutting, especially for dairy cattle. However, it requires careful use during the different periods of the year and the availability of leaf blades for grazing (ZIECH et al., 2016). Its composition observed in the spring forage emptiness (Table 1) that reinforces its potential for use not only for dairy cattle, but also for sheep and beef cattle.

All forages studied have the potential to feed ruminant herds in the spring forage, but the correct stage of harvesting or direct grazing of the animals should be observed aiming at maximum production associated with high nutritional quality (SARMADI et al., 2016). This care is necessary because the advancement in forage age causes an increase in NDF and lignin and a reduction of $\mathrm{CP}$ and soluble carbohydrates (MCDONALD et al., 2011), consequently reducing its nutritional value.

In order to optimize the utilization of forage resources and animal performance, it is ideal for the producer to plan forage for the different seasons of the year, considering the forage emptiness as the spring. In this study, tropical and temperate forages were considered and all of them have potential for use in the spring forage. In this way, the ideal is that the property maintains perennial tropical forage areas and schedules the planting of temperate forages. This scheduling allows reconciling the grazing of the animals in areas with tropical forages, which in the spring are beginning their development due to the gradual increase of temperatures and luminosity, with the temperate forage areas, which in the late implantation will be in full or advanced vegetative stage.

\section{Conclusions}

All studied forages can be used as pasture alternatives for ruminants in the spring forage emptiness of the Pampa, Brazil, however, the strategy of using them should be a fodder planning of the farms.

\section{Bibliographic References}

ALSTRUP, L.; SØEGAARD, K.; WEISBJERG, M. R. Effects of maturity and harvest season of grass-clover silage and of forage-to-concentrate ratio on milk production of dairy cows. Journal of Dairy Science, Champaign, IL, v. 99, n.1, p. 1328340,2016

BAE, H. D.; McALLISTER, T. A.; KOKKO, E.G.; LEGGETT, F. L.; YANKE, L. J.; JAKOPER, K. D.; HA, J. K.; SHIN, H. T.; GHENG, K. J. Effect of sílica on the colonization of rice strau by ruminal bacteria. Animal Feed Science and Technology, Amsterdam-NL, v. 65, p. 165-181, 1997. 
BARCELLOS, A. O.; RAMOS, A. K. B.; VILELA, L.; MARTHA JUNIOR, G. B. Sustentabilidade da produção animal baseada em pastagens consorciadas e no emprego de leguminosas exclusivas, na forma de banco de proteína, nos trópicos brasileiros. Revista Brasileira de Zootecnia, ViçosaMG, v. 37, n. esp., p. 51-67, 2008.

BARCELLOS, J. O. J.; QUEIROZ FILHO, L. A.; CEOLIN, C. A.; GIANEZINI, M.; MCMANUS, C.; MALAFAIA, G. C.; OAIGEN, R. P. Technological innovation and entrepreneurship in animal production. Revista Brasileira de Zootecnia, Viçosa-MG, v. 40, n. esp, p. 189-200. 2011.

BEZERRA, E. S.; QUEIROZ, A. C.; BEZERRA, A. R. G. F.; PEREIRA, J. C.; PAULINO M. F. Perfil granulométrico da fibra dietética sobre o tempo médio de retenção e a digestibilidade aparente de dietas para vacas leiteiras. Revista Brasileira e Zootecnia, Viçosa-MG, v. 33, n. 6, p. 2378 2386. 2004

BOLDRINI, I. I. A flora dos campos do Rio Grande do Sul. In: PILLAR, V. P.; MÜLLER S. C.; CASTILHOS Z. M. S. A.; JACQUES V. Á. Campos Sulino: conservação e uso sustentável da biodiversidade. Brasília-DF: Ministério do Meio Ambiente, 2009. p. 63-77. Disponível em: <http://ecoqua.ecologia.ufrgs.br/arquivos/Livros/CamposSulin os.pdf $>$. Acesso em: 05 ago. 2016.

CARVALHO, P. C. F.; ROCHA, L. M.; BAGGIO, C.; MACARI, S.; KUNRATH, T. R.; MORAES, A. Structural and productive characteristic of oat and ryegrass mixed pastures managed in four intensities with variable stocking rate. Revista Brasileira de Zootecnia, Viçosa-MG, v. 39, p.1857-1865, 2010.

DETMANN, E.; SILVA, J. F. C.; VÁRQUEZ, H. M. Cinética da degradação ruminal dos carboidratos de quatro gramíneas tropicais em diferentes idades de corte e doses de adubação nitrogenadas: técnica de produção de gases. Revista Brasileira de Zootecnia, Viçosa-MG, v. 38, n. 1, p. 149-158, 2009.

DETMANN, E.; VALENTE, E. E. L.; BATISTA, E. D.; HUHTANEN, P. An evaluation of the performance and efficiency of nitrogen utilization in cattle fed tropical grass pastures with supplementation. Livestock Science, Amsterdam-NL, v. 162, n. 1, p. 141-153, 2014.

DILL, M. D.; EMVALOMATIS, G.; SAATKAMP, H.; ROSSI, J. A.; PEREIRA, G. R.; BARCELLOS, J. O. J. Factors affecting adoption of economic management practices in beef cattle production in Rio Grande do Sul state, Brazil. Journal of Rural Studies, Wales-UK, v. 42, p. 21-28, 2015.

EMBRAPA. Centro Nacional de Pesquisa de Solos. Sistema Brasileiro de Classificação de Solos. 2. ed. Rio de JaneiroRJ: Embrapa Solos, 2006. 306p.

GUZATTI, G. C.; DUCHINI, P. G., SBRISSIA, A. F.; RIBEIRO-FILHO, H. M. N. Qualitative aspects and biomass production in oats and ryegrass pastures cultivated pure or intercropping and subjected to lenient grazing. Arquivo Brasileiro de Medicina Veterinária e Zootecnia, Belo Horizonte-MG, v. 67, n. 5, p. 1399-1407, 2015.

INMET. INSTITUTO NACIONAL DE METEOROLOGIA. Dados de estações climatológicas. Uruguaiana. Disponível em: <http://www.inmet.gov.br/portal/index.php?r=estacoes/estaco esAutomaticas>. Acesso em: 17 fev. 2017.

KROLOW, R. H.; SILVA, M. A.; PAIM, N. R., MEDEIROS, R. B.; GONZALEZ, H. L. Milk composition of Holstein cows grazing ryegrass with the use of white clover as a protein source. Arquivo Brasileiro de Medicina Veterinária e Zootecnia, Belo Horizonte-MG, v. 64, n. 5, p. 1352-1359, 2012.

MCDONALD, P.; EDWARDS, R. A.; GREENHALGH, J. F. D.; MORGAN, C. A.; SINCLAIR, L. A.; WILKINSON, R. G. Animal Nutrition, 7. ed. Essex, UK: Prentice Hall, 2011. p. 712 .

MERTENS, D. R. Challenges in measuring insoluble dietary fiber. Journal of Animal Science, Champaign, v. 81, n. 12, p. 3233-3249, 2003.

MEZZALIRA J. C.; CARVALHO P. C. F.; FONSECA, L.; BREMM, C.; REFFATTI, M. V.; POLI, C. H. E. C.; TRINDADE, J. K. Aspectos metodológicos do comportamento ingestivo de bovinos em pastejo. Revista Brasileira de Zootecnia, Viçosa-MG, v. 40, n. 5, p. 11141120, 2011.

MEZZOMO, R.; PAULINO, P. V. R.; DETMANN, E.; TEIXEIRA, C. R. V.; ALVES, L. C.; ASSUNÇÃO, R. N. Tannin on non-degradable digestible protein from proteic sources in cattle rumen. Acta Scientiarum. Animal Sciences, Maringá-PR, v. 37, n. 4, p. 389-395, 2015. Disponível em: < http://www.scielo.br/scielo.php?script=sci_arttext\&pid=S1807 $-86722015000400389 \& \operatorname{lng}=$ pt\&nrm=iso $>$. Acesso em: 19 fev. 2017.

NABINGER, C.; FERREIRA, E. T.; FREITAS, A. K.; CARVALHO, P. C. F.; SANT'ANNA MENEZES, D. Produção Animal com base no campo nativo: aplicação de resultados de pesquisa. In: PILLAR, V. P.; MÜLLER S. C.; CASTILHOS Z. M. S. A.; JACQUES V. Á. Campos Sulino: conservação e uso sustentável da biodiversidade. Brasília-DF: Ministério do Meio Ambiente, 2009. p. 175-198. Disponível em:

$<$ http://ecoqua.ecologia.ufrgs.br/arquivos/Livros/CamposSulin os.pdf >. Acesso em: 10 set. 2016.

NASCIMENTO, G. V.; CARDOSO, E. A.; BATISTA, N. L.; SOUZA, B. B.; CAMBUÍ, G. B. Comportamento ingestivo de vacas mestiças (holandês/zebu) sob regime de pastejo rotacionado em brachiariabrizanthacv. Marandu. Journal Behavior Biometeorology, Mossoró-RN, v. 1, n. 2, p. 31-36, 2013.

NRC. NATIONAL RESEARCH COUNCIL. Nutrient requeriments of dairy cattle. 7. ed. Washinton: D. C., 2001. $381 \mathrm{p}$.

OLIVEIRA, E. R.; MONÇÃO, F. P.; GABRIEL, A. M. A.; SILVA, L. H. X.; CARBONARI V. M. S.; PEDROSO, F. W.; PEREIRA, T. L.; NASCIMENTO, F A. Valor nutricional do colmo de gramíneas tropicais. Scientia Agraria Paranaensis, Cascavel-PR, v. 15, n. 3, p. 256-264, 2016.

OLIVO, C. J.; MEINERZ, G. R.; AGNOLIN, C. A.; STEINWANDTER, E.; ZIECH, M. F.; SKONIESKI, F. R. Produção de forragem e carga animal de pastagens de Coastcross sobressemeadas com forrageiras de inverno. 
Revista Brasileira de Zootecnia, Viçosa-MG, v. 39, n. 1, p. 68-73, 2010.

PAIVA, J. A. J.; GARCIA, R.; QUEIROZ, A. C.; REGAZZI, A. J. Efeitos dos níveis de amônia anidra e períodos de amonização sobre os teores dos constituintes da parede celular na palhada de milho. Revista Brasileira de Zootecnia, Viçosa-MG, v. 24, n. 5, p. 683-691, 1995.

PARIS, W.; TONION, R.; MARTINELLO, C.; SARTOR, L. R.; PAULA, F. L. M.; OLIVEIRA, J. D. Productivity and nutritional value of African Star managed with different leaf blade mass. Acta Scientiarum. Animal Sciences, MaringáPR, v. 38, n. 1, p. 31-36, 2016.

PERES NETTO, D.; RIBEIRO, A. R. B.; RODRIGUES, A. A.; FERREIRA, R. P.; MENDONÇA, F. C.; FREITAS, A. R.; CAMPANA, M.; WECHSLER, F. S. Diurnal behavior of dairy cows on alfalfa pastures supplemented with corn silage and concentrate. Arquivo Brasileiro de Medicina Veterinária e Zootecnia, Belo Horizonte-MG, v. 66, n. 3, p. 837-844, 2014.

RUPPENTAL, V.; ZOZ, T.; STEINER, F.; LANA, M. C.; CASTAGNARA, D. D. Silicon does not alleviate the adverse effects of drought stress in soybean plants. Semina: Ciências Agrárias, Londrina-PR, v. 37, n. 6, p. 3941-3954, 2016.

SARMADI, B.; ROUZBEHAN, Y.; REZAEI, J. Influences of growth stage and nitrogen fertilizer on chemical composition, phenolics, in situ degradability and in vitro ruminal variables in amaranth forage. Animal Feed Science and Technology, Amsterdam-NL, v. 215, p. 73-84, 2016.
SILVA, D. J.; QUEIROZ, A. C. Análise de alimentos: métodos químicos e biológicos. 3 ed. Viçosa-MG: UFV, 2009. $235 \mathrm{p}$.

STROSCHEIN, M. R. D.; WALLAU, M. O; DE SÁ, E. L.S.; BINZ, A.; AGNOL, M. D. Seleção a campo de rizóbios nativos para cornichão. Ciência Rural, Santa Maria-RS, v. 41, n. 10, p. 1769-1772, 2011.

TAIZ, L.; ZEIGER, E. Fisiologia Vegetal. 4.ed. Porto AlegreRS: Artmed, 2009. 820 p.

TEIXEIRA, J. C.; TEIXEIRA, L. F. A. C. Do Alimento ao Leite: Entenda a Função Ruminal. Lavras-MG: Fundação de Apoio ao Ensino, Pesquisa e Extensão, 1998. 72 p.

VAN SOEST, P. J. Nutritional ecology of the ruminant. 2. ed. Ithaca: Cornell University Press, 1994. 476 p.

VIBART, R. E.; BURNS, J. C.; FELLNER, V. Effect of Replacing Total Mixed Ration with Pasture on Ruminal Fermentation. The Professional Animal Scientist, Champaign, IL, v. 26, n. 4, p. 435- 442, 2010.

ZIECH, M. F.; OLIVO, C. J.; MEINERZ, G. R.; AGNOLIN, C. A.; SKONIESKI, F. Ingestive behavior of dairy cows grazing intercropped pastures in warm season. Ciência Animal Brasileira, Goiânia-GO, v. 17, n. 2, p. 198-205, 2016. 